\title{
Observations on metamorphosing tadpoles of Hyalinobatrachium orientale (Anura: Centrolenidae)
}

\author{
Isabel Byrne, ${ }^{1}$ Robyn Thomson, ${ }^{1}$ Rory Thomson, ${ }^{1}$ Duncan Murray-Uren, ${ }^{1}$ and J. Roger Downie ${ }^{1}$ \\ School of Life Sciences, Graham Kerr Building, University of Glasgow. Glasgow G12 8QQ, Scotland, United Kingdom. \\ E-mail: isabelbyrne11@gmail.com.
}

\begin{abstract}
Observations on metamorphosing tadpoles of Hyalinobatrachium orientale (Anura: Centrolenidae). Metamorphosis, when anuran amphibians resorb their tails and remodel their mouthparts and internal organs, is a vulnerable stage in the frog's life history. As larvae metamorphose from tadpoles to adult frogs, they are neither suited to aquatic life nor ready for active terrestrial life. Previous studies have examined the duration of metamorphosis in a range of species, with respect to tadpole size, habitat, and other factors; however, the duration of metamorphosis relative to where it takes place has not been reported in centrolenids. In Hyalinobatrachium orientale, metamorphosis takes place on the upper surfaces of the leaves of low understory plants and lasts 3.5-4.0 days, a little longer than expected for the tadpole of this body size. Metamorphs seem to shift their perches from leaf to leaf randomly. There are no significant differences in the temperature or relative humidity of the upper and lower surfaces of leaves in the forest understory; thus, the presence of the metamorphs on the upper surfaces of leaves may provide moisture from the upper story vegetation after rain and protect them from terrestrial predators.
\end{abstract}

Keywords: Anurans, Tobago Glass Frog, life history, metamorphic duration.

\begin{abstract}
Resumo
Observações sobre girinos de Hyalinobatrachium orientale (Anura: Centrolenidae) em metamorfose. A metamorfose, processo em que os anfíbios anuros reabsorvem suas caudas e remodelam suas partes bucais e órgãos internos, é um estágio vulnerável de sua história de vida. Durante a transformação de larvas em adultos, os girinos não estão bem adaptados à vida aquática nem à vida terrestre ativa. Estudos anteriores examinaram a duração da metamorfose em diversas espécies com relação ao tamanho do girino, habitat e outros fatores; entretanto, a duração da metamorfose em relação ao local onde esta ocorre não foi relatada pantrolenídeos. Em Hyalinobatrachium orientale, a metamorfose ocorre nas superfícies superiores das folhas das plantas de sub-bosque baixo e dura de 3,5 a 4,0 dias, um pouco mais do que o esperado para um girino desse tamanho de corpo. Os indivíduos recém-metamorfoseados parecem mudar seus poleiros de folha para folha aleatoriamente. Não há diferenças significativas na temperatura ou umidade relativa das superfícies superior e inferior das folhas no sub-bosque da floresta; assim, o uso das superfícies superiores das folhas pode fornecer-lhes umidade da vegetação do estrato superior após as chuvas e protegê-los de predadores terrestres.
\end{abstract}

Palavras-chave: anuros, duração da metamorfose, história natural, pererecas-de-vidro-de-tobago.

Received 13 November 2019

Accepted 26 June 2020

Distributed December 2020 


\section{Introduction}

The transformation of anuran larvae into froglets during metamorphosis is a crucial stage in the life history of anurans. Because the metamorphs are neither well suited to aquatic life nor ready for life on land, they are vulnerable. For this reason, Wassersug and Sperry (1977) suggested that the period of metamorphosis is likely to be subject to minimizing selection. However, in a survey of 14 taxonomically diverse species, Downie et al. (2004) reported that metamorphic duration ranges from 2.0-7.3 days and that it is correlated with body sizes of the tadpoles and ecological factors, such as external temperature. The authors also noted that species that resorb the tail quickly emerge from the water early, whereas species in which the tail is retained longer, usually emerge from the water later. The survey included seven tree frog species from Trinidad, five being early emergers and two late.

There is no information about metamorphic behavior in centrolenid frogs, a diverse lineage comprising more than 160 species (AmphibiaWeb 2020). Hoffmann (2010) described the morphology of 13 species of centrolenid tadpoles. He achieved growth and development in captivity until just before metamorphosis (i.e. Gosner 1960, Stage 41) in two of these species. He noted that it is difficult to study centrolenid development because typically, the larvae live hidden in the stream substrate and they are difficult to maintain in captivity.

The Tobago population of the glass frog Hyalinobatrachium orientale is distinct enough from the Venezuelan population to merit subspecies designation as tobagoense (Jowers et al. 2014). Parental care (Lehtinen and Georgiadis 2012), development to hatching (Nokhbatolfoghahai et al. 2015), early tadpole morphology (Downie et al. 2015), and early tadpole behavior (Byrne et al. 2018) have been described in Hyalinobatrachium orientale. Herein, we report observations on metamorphosing individuals found in the field.

\section{Materials and Methods}

We surveyed six streams in northeastern Tobago (Figure 1) for Hyalinobatrachium orientale from June-August for each of the years 2016-2019. Surveys were conducted by teams of two to five observers who walked up the streams at night, locating glass frogs either visually or acoustically or searched the streams during the day for metamorphs and egg clutches. The tail and snout-vent lengths (SVL) of metamorphs were measured with dial callipers accurate to 0.1 $\mathrm{mm}$. In addition, the distance of the metamorph from the nearest stream was recorded, as well as its height above ground (with a tape measure accurate to $1.0 \mathrm{~mm}$ ) and location-i.e., on the ground or on a plant (leaf upper or lower side, or stem). To test the hypothesis that metamorphs move further away from streams as they develop, a one way ANOVA (analysis of variance) was conducted to examine the effect of tail length on metamorph height above the stream and metamorph distance from stream. In 2019, we marked the locations of the plants using white paper held by a stone, so that the original position of the metamorphs could be easily relocated on subsequent visits, often 3 or 4 days apart. In 2019, we transferred three metamorphs to our base in Charlotteville, where they were kept as individuals in plastic aquarium tanks containing a substrate of leaves and damp leaf litter. We assessed the rate of tail resorption in these individuals by measuring tail length daily until only a stump remained. The locations of the metamorphs in the tanks were recorded to monitor their movements. After metamorphosing, the frogs were released at their original locations.

In 2016, we measured two microhabitat parameters-viz., temperature and relative humidity. Eight Tiny Tag-2 dataloggers (Gemini, UK) that record temperature (accurate to $0.4^{\circ} \mathrm{C}$ in the $20-30^{\circ} \mathrm{C}$ range) and relative humidity (accurate to $\pm 3.0 \%$ at $25^{\circ} \mathrm{C}$ ), were attached with duct tape to the upper and lower 


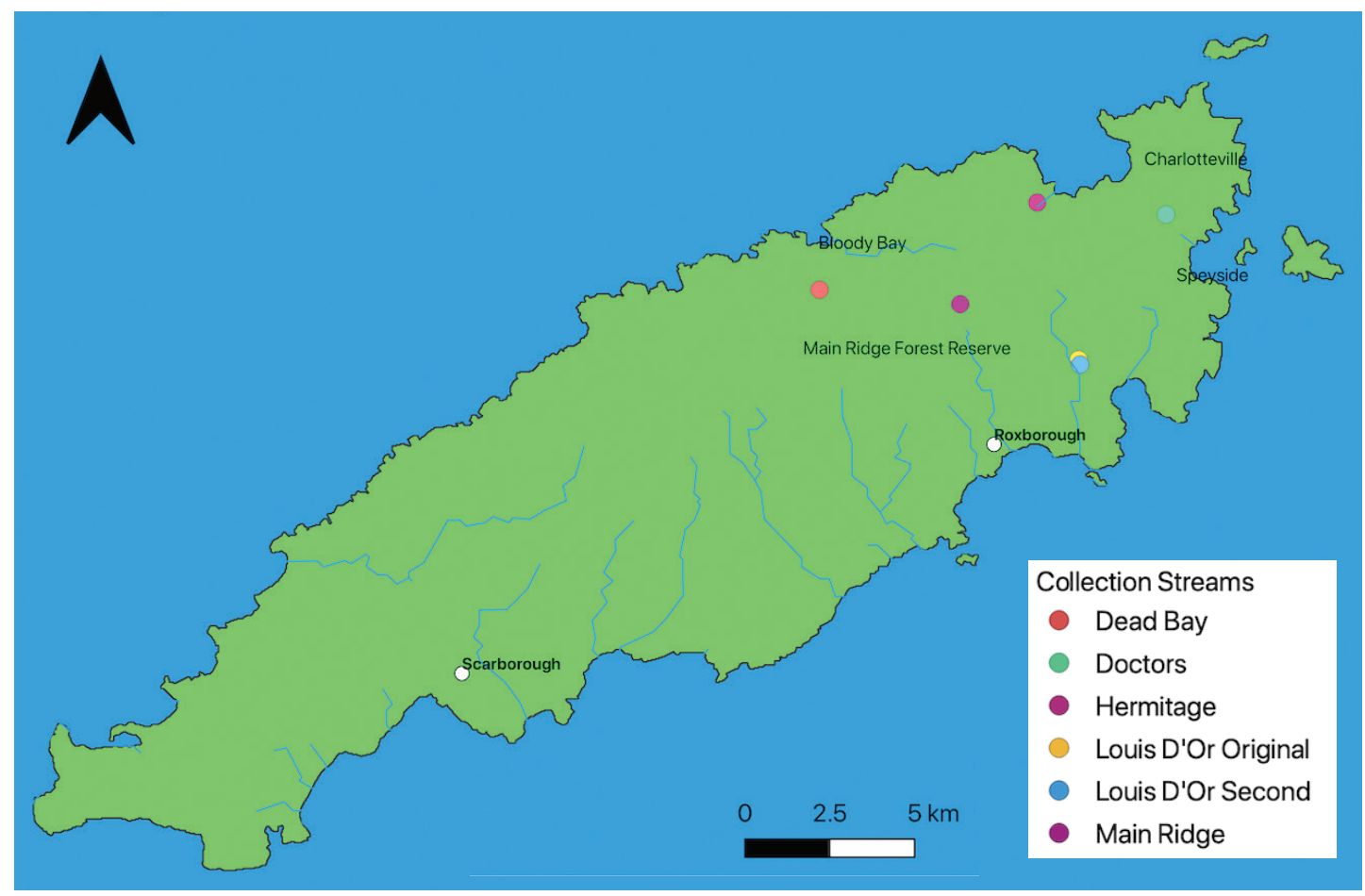

Figure 1. Map of Tobago showing the glass frog localities visited in the northeast. Map created using QGIS 3.12.

leaf surfaces of Heliconia bihai along four streams (Dead Bay, Main Ridge, Doctor's, and Hermitage) where glass frogs were found (Figure 1). The data loggers were deployed for 42 consecutive days in June and July and set to record once every six hours (168 recordings by each data logger). The timing of these recordings varied among the different sites, but are grouped, as follow: "Early morning," 01:30-05:30 h; "mid-morning," 07:30-11:30 h; "afternoon," 13:30-17:30 h; and "early night," 20:45-23:45 h. Data were extracted using Tiny Tag Explorer version 4.10. Site altitudes were measured using a Garmin hand-held satellite GPS. A one way ANOVA was conducted to test the effect of leaf side on temperature and humidity. The test was run for each set period of the day. Data analyses were completed using $\mathrm{R}$ software.

\section{Results}

Adult Hyalinobatrachium orientale and egg clutches were found on the undersides of leaves overhanging the streams; the frogs were found perched on leaves less than a meter above the stream to perches several meters high, usually on the leaves of Heliconia bihai. This general observation is based on several years of data collection, as follow: 2016, 29 surveys between 19 June and 18 August yielded 9 metamorphs and 156 egg clutches, as well as adults; 2017, 33 surveys between 20 June and 21 August yielded 10 metamorphs and 257 clutches; 2018, 1 survey on 20 June produced 3 metamorphs; and 2019, 24 surveys between 17 June and 25 July yielded 31 metamorphs. A total of 53 metamorphs was found in the 4-year study, and tail lengths were measured of 42 metamorphs in the field, with the 
following results: six had the short tails $(0-5.0$ $\mathrm{mm}$ ); nine had tails $5.1-10.0 \mathrm{~mm}$ long; $17 \mathrm{had}$ tail lengths of $10.1-15.0 \mathrm{~mm}$; and 10 had tails that were 15.1-20 mm long. Although these data seem to reflect a reduction in the proportions of the size classes during the 4 days of metamorphosis, a test of the results compared to the null hypothesis gives chi squared (three degrees of freedom) $=6.12, p>0.05$, a nonsignificant difference.

Metamorphs were found on the upper sides of the leaves of small plants (e.g., shrubs and tree seedlings of several different species); none was found on the ground (Figure 2). The heights of the perches ranged from $15-245 \mathrm{~cm}$, and their distances from the stream from 0 ( 1 individual on a leaf immediately above a stream) to 300 $\mathrm{cm}$. We hypothesized that initially, metamorphs would utilize the nearest leaf encountered after leaving the water (i.e., low height; short distance from water) and then move higher and farther away as metamorphosis progressed, but we found no relationship between tail length and height on plant or distance from stream (ANOVA, $p=$ 0.13 for height; $p=0.14$ for distance; $N=34$ ).

No metamorph was found at the same location $24 \mathrm{hr}$ later. Likewise, we observed that the captive metamorphs were not immobile, moving from their original leaf to new perches and substrates within the container.

The coloration of metamorphic Hyalinobatrachium orientale resembles that of adults-i.e., green dorsally and transparent ventrally (Figure $3 \mathrm{~A}, \mathrm{~B})$. Tail resorption in the three captive metamorphs was completed in 4 days (16.3-1.0 $\mathrm{mm}), 3.5$ days $(14.9-0.9 \mathrm{~mm})$ and 3.5 days $(15.0-0.7 \mathrm{~mm}$ ), respectively (Figure 2C, D). The digestive tract and other internal organs were most clearly defined in metamorphs with the shortest tails. The three longest tails measured in the field were 19.0, 19.5, and $20.0 \mathrm{~mm}$ (54.3, 59.9 , and $60.0 \%$ of total length, respectively). Mean body length (SVL) at the end of metamorphosis, taken as short tail stump stage $(<2.0 \mathrm{~mm}$ ) was $10.8 \pm 1.3 \mathrm{~mm}$ (range $8.9-13.6$ $\mathrm{mm} ; N=9)$.
Temperature and relative humidity data from Heliconia leaves are shown in Table 1. The highest and lowest temperatures recorded were $34.8^{\circ} \mathrm{C}$ at Hermitage on the upper side of a leaf and $21.5^{\circ} \mathrm{C}$ at Main Ridge on the upper side of a leaf. The highest and lowest relative humidities recorded were $100 \%$ which was recorded at all locations, and $89 \%$ at Hermitage on the top side of a leaf. An analysis of variance showed no significant differences between top and lower sides of leaves at any of the locations or at any time of day for both temperature and humidity (ANOVA, $p>0.4$ for all comparisons). Temperature changed only a little over the daily cycle, with the peak occurring in the afternoon. Relative humidity was always high, with the lowest values in the afternoon. Highland sites were a little cooler than lowland sites, but there was no difference in humidity.

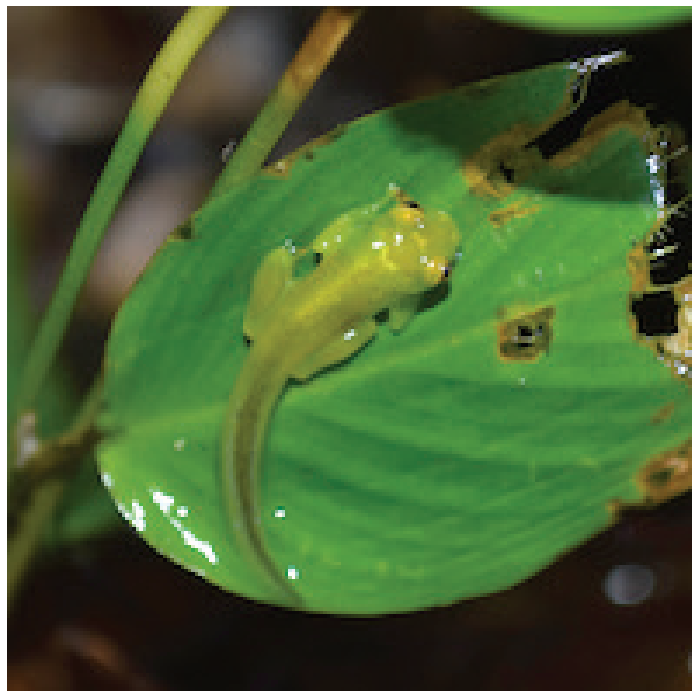

Figure 2. Metamorph of Hyalinobatrachium orientale perched on the upper side of a plant leaf.

\section{Discussion}

Although our sample size is too small to determine the duration of metamorphosis with accuracy, and we lack data for metamorphs with 

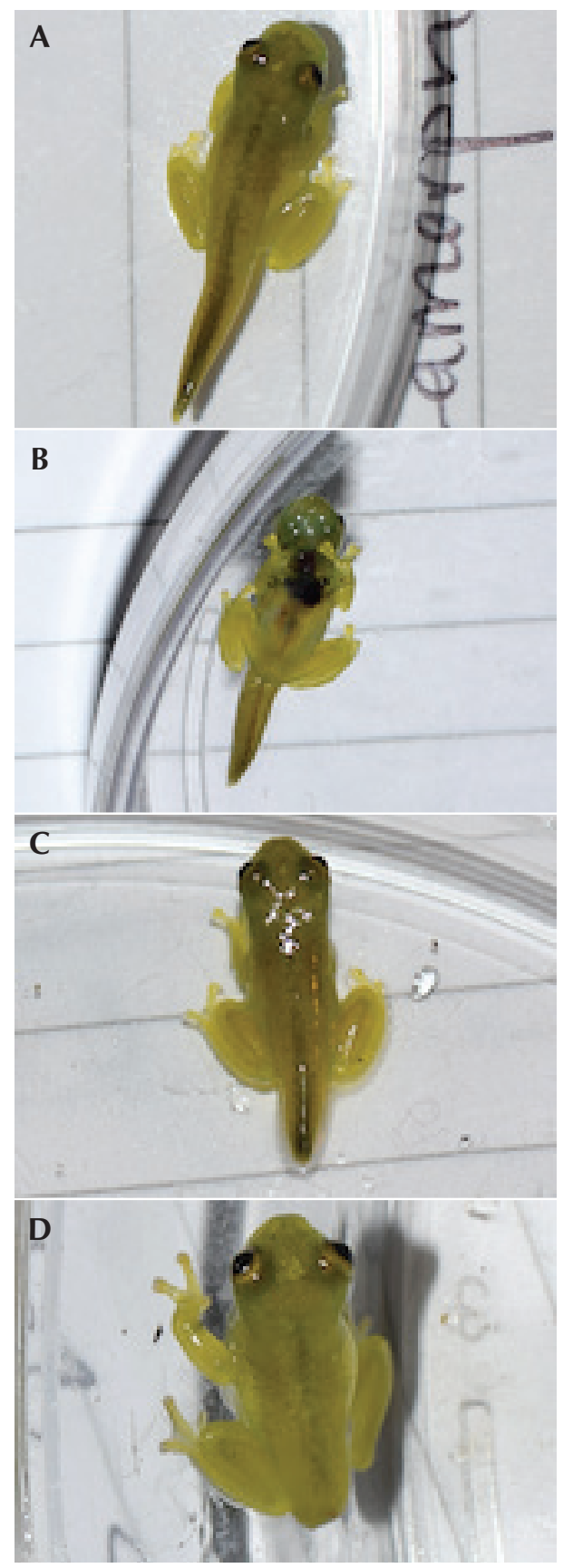

Figure 3. Metamorphs of Hyalinobatrachium orientale photographed in captivity. Early-stage metamorph in dorsal (A) ventral (B) views. Dorsum of midstage metamorph $(\mathbf{C})$. Dorsum of late-stage metamorph tail stump (D). the longest tails $(19-20 \mathrm{~mm})$, our data indicate that metamorphosis lasts slightly more than 3.5 days $(3.6 \pm 0.2)$. In their comparison of metamorphosis duration in 14 tadpole species representing five families (Hylidae, Leptodactylidae, Pipidae, Dendrobatidae, and Bufonidae), Downie et al. (2004) estimated that metamorphosis was completed in slightly more than three days in tadpoles with a maximum tail length of $20 \mathrm{~mm}$. Thus, Hyalinobatrachium orientale is taking a little longer than expected, but we do not know how long forelimb emergence (the start of metamorphosis) takes before we find metamorphs on leaves. Crump (1984) found that hylid metamorphs left the water soon after forelimb emergence, as did Downie et al. (2004).

In amphibians, the duration of metamorphic climax has a direct relationship with environmental temperature, accelerating as temperature rises (Walsh et al. 2008, Downie et al. 2004). Our sample was too small to determine the effect of temperature on the duration of metamorphosis in the captive metamorphs.

Wassersug and Sperry (1977) hypothesized that high predation levels during the vulnerable stage of metamorphosis would lead to short metamorphic durations. Our finding that metamorphs of Hyalinobatrachium orientale always perched on the upper sides of leaves suggests that this may be a strategy to avoid ground-dwelling predators. Mating adults and egg clutches always are found on the lower sides of leaves (Nokhbatolfoghahai et al. 2015), but these leaves are over water. There are some 10 species of snakes on Tobago (Auguste 2018) that may prey on small frogs and most likely would approach from the ground. We analyzed our data for evidence of predator pressure; if predators are successful, one would expect that metamorphs with the shortest tails would be the least numerous. However, we found no significant difference in the proportions of size classes in the 42 metamorphs. Other potential predators include bats, crabs, and some insects, but well camouflaged, silent and mainly motionless metamorphs may be difficult for predators to locate. 
Table 1. Mean temperature and relative-humidity values for upper and lower sides of leaves at different times of day and at different altitudes (Lowland sites: Hermitage, 39 m; Doctor's, 65 m. Highland sites: Main Ridge, 420 m; Dead Bay, 206 m).

\begin{tabular}{lccccc}
\hline \multirow{2}{*}{ Site } & Time Period & \multicolumn{2}{c}{ Temperature $\left({ }^{\circ} \mathbf{C}\right)$} & \multicolumn{2}{c}{ Humidity $(\%)$} \\
\cline { 3 - 5 } & & Upper & Lower & Upper & Lower \\
\hline \multirow{2}{*}{ Lowland } & Early Morning & $25.1 \pm 0.7$ & $25.3 \pm 0.7$ & $99.2 \pm 2.4$ & $99.4 \pm 2.3$ \\
& Mid-morning & $26.8 \pm 1.7$ & $26.8 \pm 1.7$ & $93.9 \pm 7.5$ & $94.0 \pm 7.5$ \\
& Afternoon & $27.9 \pm 1.9$ & $28.3 \pm 2.1$ & $89.5 \pm 8.2$ & $89.4 \pm 8.6$ \\
\hline Highland & Early night & $25.6 \pm 0.7$ & $25.7 \pm 0.7$ & $97.8 \pm 2.8$ & $98.9 \pm 2.3$ \\
& Early Morning & $23.8 \pm 1.2$ & $23.9 \pm 1.9$ & $98.9 \pm 4.5$ & $98.8 \pm 4.8$ \\
& Mid-morning & $24.6 \pm 1.1$ & $24.7 \pm 1.0$ & $98.3 \pm 5.2$ & $98.4 \pm 5.2$ \\
& Afternoon & $26.2 \pm 1.8$ & $25.9 \pm 1.6$ & $93.4 \pm 7.7$ & $94.3 \pm 6.4$ \\
& Early night & $24.2 \pm 1.4$ & $24.3 \pm 1.4$ & $98.4 \pm 4.5$ & $98.5 \pm 4.9$ \\
\hline
\end{tabular}

The mobility of the metamorphs needs more investigation. Our data do not support the hypothesis that metamorphs would move to higher locations or farther from the stream as metamorphosis progressed. Metamorphs might move to confuse potential predators or perhaps the froglets are searching for moisture to avoid dehydration through cutaneous water loss, which is likely given the high surface area/volume ratio of small frogs compared to larger ones (Levy and Heald 2016).

The variation in numbers of clutches and metamorphs found year to year reflects different objectives of each year's fieldwork. In 2016 and 2017, we focused on centrolenid clutches and their development, but less so in 2018; in 2019, we emphasized collecting data on metamorphs.

We explored whether metamorphs on the upper surfaces of leaves are subject to more water loss than those on lower surfaces. Because the leaves on which the metamorphs typically perched were too small to support the weight of the TinyTag data loggers, temperature and humidity data were recorded from the leaves of Heliconia, which have a similar surface texture to those used by metamorphs. Hyalinobatrachium orientale typically deposits it egg clutches on leaves of Heliconia bihai if it is present (Byrne et al. unpubl. data). Relative humidity and temperature readings at the upper and lower surfaces of leaves are similar-doubtless because these understory plants usually are near streams in tropical rain forests, where neither direct sunlight nor direct rainfall usually penetrates. In addition, temperatures varied only slightly across the daily cycle. By perching on the upper surfaces of leaves, metamorphs will be hydrated by water that drips from the upper canopy when it rains.

\section{Acknowledgments}

We acknowledge financial assistance from several sources, especially the University of Glasgow, Glasgow Natural History Society and the British Chelonia Group for travel grants. The Percy Sladen Bequest funded purchase of the data loggers. We thank several people for assistance with fieldwork, especially members of the 2016, 2017 and 2018 University of Glasgow Tobago expeditions, Paul Hoskisson and Renoir Auguste. We thank the two anonymous reviewers for their helpful comments. 


\section{References}

AmphibiaWeb. 2020. Information on amphibian biology and conservation. Accessible at https://amphibiaweb.org/. Berkeley, California: AmphibiaWeb. Captured on 07 May 2020.

Auguste, R. J. (ed.). 2018. A Field Guide to the Amphibians and Reptiles of Trinidad and Tobago. Trinidad and Tobago. Trinidad and Tobago Field Naturalists' Club. 336 pp.

Byrne, I., C. Judge, and J. R. Downie. 2018. The behaviour of recently hatched Tobago glass frog tadpoles. Herpetological Bulletin 144: 1-4.

Crump, M. L. 1984. Ontogenetic changes in vulnerability to predation in tadpoles of Hyla pseudopuma. Herpetologica 40: $265-271$.

Downie, J. R., R. Bryce, and J. Smith. 2004. Metamorphic duration: an under-studied variable in frog life histories. Biological Journal of the Linnean Society 83: 261-272.

Downie, J. R., M. Nokhbatolfoghahai, and L. Christie. 2015. The tadpole of the glass frog Hyalinobatrachium orientale tobagoense (Anura: Centrolenidae) from Tobago, West Indies. Herpetological Bulletin 131: 19-21.

Gosner, K. L. 1960. A simplified table for staging anuran embryos and larvae with notes on identification. Herpetologica 16: 183-190.

Hoffmann, H. 2010. The glass frog tadpoles of Costa Rica (Anura: Centrolenidae): a study of morphology. Abhandlungen der Senckenberg Gesellschaft fur Naturforschung 567: 1-78.
Jowers, M. J., R. M. Lehtinen, J. R. Downie, A. P. Georgiadis, and J. C. Murphy. 2014. Molecular phylogenetics of the glass frog Hyalinobatrachium orientale (Anura: Centrolenidae): evidence for Pliocene connections between mainland Venezuela and the island of Tobago. Mitochondrial DNA 26: 613-618.

Lehtinen, R. M. and A. P. Georgiadis. 2012. Observations on parental care in the glass frog Hyalinobatrachium orientale (Anura: Centrolenidae) from Tobago, with comments on its natural history. Phyllomedusa 11: 7577.

Levy, D. L. and R. Heald. 2016. Biological scaling problems and solutions in Amphibians. Cold Spring Harbour Perspectives in Biology 8: 1-17.

Nokhbatolfoghahai, M., C. J. Pollock, and J. R. Downie. 2015. Oviposition and development in the glass frog Hyalinobatrachium orientale (Anura: Centrolenidae). Phyllomedusa 14: 3-17.

Walsh, P. T., J. R. Downie, and P. Monaghan. 2008. Predation-induced plasticity in metamorphic duration in Xenopus laevis. Functional Ecology 22: 699-705

Wassersug, R. J. and D. G. Sperry. 1977. The relationship of locomotion to differential predation on Pseudacris triseriata (Anura: Hylidae). Ecology 58: 830-839.

Editor: Jaime Bertoluci 